\title{
Correction to: Efficacy of single-site radiotherapy plus PD-1 inhibitors vs PD-1 inhibitors for oligometastatic non-small cell lung cancer
}

\author{
Peiliang Wang ${ }^{1} \cdot$ Tianwen Yin $^{1} \cdot$ Kaikai Zhao ${ }^{2} \cdot$ Jinming $\mathrm{Yu}^{1} \cdot$ Feifei Teng ${ }^{1,3}$ (I)
}

Published online: 8 December 2021

(c) The Author(s) 2021

\section{Correction to: Journal of Cancer Research and Clinical Oncology https://doi.org/10.1007/s00432-021-03849-3}

In the original article published, the authors Peiliang Wang and Tianwen Yin are co-first authors and have equally contributed to this work.

The original article has been corrected.

Open Access This article is licensed under a Creative Commons Attribution 4.0 International License, which permits use, sharing, adaptation, distribution and reproduction in any medium or format, as long as you give appropriate credit to the original author(s) and the source, provide a link to the Creative Commons licence, and indicate if changes were made. The images or other third party material in this article are included in the article's Creative Commons licence, unless indicated otherwise in a credit line to the material. If material is not included in the article's Creative Commons licence and your intended use is not permitted by statutory regulation or exceeds the permitted use, you will need to obtain permission directly from the copyright holder. To view a copy of this licence, visit http://creativecommons. org/licenses/by/4.0/.

Publisher's Note Springer Nature remains neutral with regard to jurisdictional claims in published maps and institutional affiliations.

The original article can be found online at https://doi.org/10.1007/ s00432-021-03849-3.

Feifei Teng

tengfeifei16@126.com

1 Department of Radiation Oncology, Shandong Cancer Hospital and Institute, Cheello College of Medicine, Shandong University, Jiyan Road 440, Jinan 250117, Shandong Province, People's Republic of China

2 Department of Radiation Oncology, Yantai Afliated Hospital of Binzhou Medical University, Yantai, Shandong, People's Republic of China

3 Department of Radiation Oncology, Shandong Cancer Hospital and Institute, Shandong First Medical University, Shandong Academy of Medical Sciences, Jinan, Shandong, People's Republic of China 